$2020,21(1)$, pp. 199 - 204, DOI: 10.18038/estubtda. 622224

\title{
DETERMINATION OF THE CONTENT OF HYOSCYAMUS RETICULATUS SEEDS BY XRF METHOD AND ANTIBACTERIAL CHARACTERISTICS OF ETHYL ALCOHOL EXTRACT*
}

\author{
Perihan AKBAŞ ${ }^{1}$, Elife KAYA², Hicran ALKAN², Gökhan CEYHAN² \\ ${ }^{1}$ Department of Medical Technical Services, Atatürk Vocational School of Health Services, Kafkas University, Kars, Turkey \\ ${ }^{2}$ Department of Food Processing, Vocational School of Technical Sciences, Kahramanmaraş Sütçü İmam University, \\ Kahramanmaraş, Turkey \\ ${ }^{3}$ Department of Child Development, Vocational School of Social Sciences, Kafkas University, Kars, Turkey
}

\begin{abstract}
Hyoscyamus reticulatus is a member of the family Solanaceae and is represented by six species in Turkey. Hyoscyamus species contain important tropane alkaloids, which have antispasmodic, anticholinergic, analgesic, and sedative effects. In this study, we aimed to determinate the contents of Hyoscyamus reticulatus seeds by X-ray fluorescence (XRF) spectrometry and investigate the antibacterial activity of the ethanol extract of $\mathrm{H}$. reticulatus seeds. Energy-dispersive XRF spectrometry is one of the important approaches used to determine the elemental and chemical composition of all types of liquids and solids, allowing quick and accurate qualitative and quantitative analysis of elements. In this study, contents of $H$. reticulatus seeds were determined by XRF method as follows: $1.98 \% \mathrm{~K}_{2} \mathrm{O}(1.65 \mathrm{~K} \%), 1.22 \% \mathrm{P}_{2} \mathrm{O}_{5}(0.53 \mathrm{P} \%), 0.80 \% \mathrm{SO}_{3}(0.32 \% \mathrm{~S}), 0.49 \% \mathrm{CaO}(0.35 \mathrm{Ca} \%), 0.26 \%$ $\mathrm{Fe}_{2} \mathrm{O}_{3}(0.18 \% \mathrm{Fe}), 0.13 \% \mathrm{Cl}, 0.11 \% \mathrm{MgO}(0.07 \% \mathrm{Mg}), 0.10 \% \mathrm{ZnO}(0.08 \% \mathrm{Zn}), 0.06 \% \mathrm{MoO}_{3}(0.04 \% \mathrm{Mo}), 0.05 \% \mathrm{SiO}_{2}(0.02 \%$ $\mathrm{Si}), 0.02 \% \mathrm{Cu}$, and $0.02 \% \mathrm{MnO}(0.01 \% \mathrm{Mn})$, while $\mathrm{NiO}(67 \mathrm{ppm})$ and $\mathrm{Al}_{2} \mathrm{O}_{3}(94 \mathrm{ppm})$ were determined at the ppm level. $H$. reticulatus seeds were treated by extraction for antibacterial activity tests and Escherichia coli, Pseudomonas aeruginosa, Pasteurella multocida, Yersinia enterocolitica, Klebsiella pneumoniae, Staphylococcus aureus, and Salmonella enteridis bacteria were used. The extract affected no bacteria except for Pasteurella multocida $(10 \mathrm{~mm})$.
\end{abstract}

Keywords: Hyoscyamus reticulatus seed extract, Antibacterial, XRF

*This study was presented as a summary at the International Conference on Research in Education and Science (ICRES-2018).

\section{INTRODUCTION}

In Turkey, the genus Hyoscyamus, a member of the family Solanaceae, is known by common names such as henbane, deli bat bat, gavur haşhaşı, bengildek, berç, benk, and dağdağan. Six Hyoscyamus species are found in Turkey, including $H$. albus L., H. aureus L., H. leptocalyx Stapf., H. niger L., $H$ pusillus L., and H. reticulatus L. H. reticulatus has purple flowers and more feathered leaves with deeptoothed edges; its taste is bitter and its flowers have an unpleasant odor [1].

H. reticulatus has tropane alkaloids such as atropine, scopolamine, and hyoscyamine with anticholinergic effects and nonalkaloid secondary metabolites (withanolides, flavonoids, lignans, cumarinolignans, saponins, glycerides, glycosides, and phenolics). These alkaloids are widely used for their mydriatic, antispasmodic, anticholinergic, analgesic, and sedative properties [2]. Since it has pharmacologically active substances, it has attracted the attention of researchers, and antioxidant and antimicrobial studies of this species have been reported. When the ethanolic extract of $\mathrm{H}$. reticulatus leaves was analyzed, total phenolic content was found to be $130.06 \mathrm{mg} / \mathrm{g}$ and total flavonoid content was $243.7 \mathrm{mg} / \mathrm{g}$ [3]. Although there are no data on material losses due to poisoning caused by poisonous plants in Turkey, it is reported that approximately 3\%-5\% of animals are poisoned with plants every year in countries where pasture improvement is done, such as the United States [4].

Plant poisoning cases are also found in humans. People in rural areas who cannot easily find fresh vegetables often eat whatever they can procure. Because the taste of the leaves and roots of henbane is

Corresponding Author: perihanakbas36@gmail.com

Received: 19.09.2019 Published: 31.03.2020 
similar to that of cucumber, it attracts children. The poisoning of two people who ate fresh shoots of Hyoscyamus niger because of its similarity to lettuce is an example, and henbane poisoning is common in Eastern Anatolia [5, 6, 7]. Consumption of the fresh shoots, roots, and seeds of $H$. niger can cause hallucinations, blurred vision, increased heart rhythm, and death [2, 3, 8, 9]. Similarly, a 71-year-old patient with a diagnosis of bronchial asthma drank tea made from the leaves of many henbane plants because he had heard it was good for asthma, and approximately two hours later, he was hospitalized with symptoms including visual and speech disorders, dry mouth, and palpitations [10].

In Turkey, which has a rich variety of plants because of its geographical location and the presence of important gene centers, it consists of the plant species in the natural healing source. Recent studies focused on the effects of antioxidant substances and phenolic compounds in plants on healthy life. These plants (green tea, nettle, aloe vera, thyme, peppermint, mountain tea, rosemary, etc.) contain some basic compounds such as organic acids, antioxidants, polyphenols, proteins, vitamins and elements as natural healing sources [11,12].

Healthy nutrition with natural food resources has become difficult today due to the development of technology and technological products. As a result of these, the number of factors that directly and indirectly threaten human health is increasing. Therefore, the healthy nutrition of people in their local environments is very important, as is how to identify healthy food. One of these methods is the X-ray fluorescence (XRF) method. Energy-dispersive XRF spectrometers are important devices used in determining the elemental and chemical compositions of all kinds of liquid and solid samples. They enable the qualitative and quantitative analysis of elements to be performed quickly and accurately. Understanding the structure of a sample with this method is very useful for guidance in advanced stages of analysis [13].

Antioxidant and antimicrobial effects of the leaf extracts of $H$. reticulatus, which cause poisoning, have been investigated, but elemental chemical analyses and antimicrobial studies of the seeds, where the active substances are expected to be more densely found, are not sufficient.

In this study, it is aimed to determine the antimicrobial activity of the ethyl alcohol extract obtained from $H$. reticulatus seeds against some Gram-positive and Gram-negative bacteria and to perform elemental chemical analysis of the seed contents of $H$. reticulatus by the XRF method.

\section{MATERIALS}

\subsection{Plant Material}

The seeds of $H$. reticulatus used in the experiments were obtained from the province of Kars and were ground and prepared for analysis.

\subsection{Microorganisms}

Standard strains of Salmonella enteridis (ATCC 13076), Escherichia coli (ATCC 25922), Klebsiella pneumoniae (ATCC 4352), Pasteurella multocida (ATCC 12945), Pseudomonas aeruginosa (ATCC 27853), Staphylococcus aureus (ATCC 6538), and Yersinia enterocolitica (ATCC 27729) were used to determine the antimicrobial effects of $H$. reticulatus seed extract.

\section{METHODS}

\subsection{Preparation of $\boldsymbol{H}$. reticulatus Seed Extract}

All chemicals and solutions were of analytical purity. H. reticulatus seeds were finely powdered, and the powder was diluted with water and ethanol (water : ethanol, $2: 8$ ) in a ratio of $1: 5$ and left in a shaking water bath for 48 hours at room temperature. After 48 hours, the mixture was filtered through 
filter paper and evaporated under reduced pressure at $50{ }^{\circ} \mathrm{C}$ in the evaporator, whereby the water and alcohol were evaporated [14].

\subsection{Preparation of Microorganism Cultures and Agar Well Diffusion Technique}

The agar well diffusion method is used to determine antimicrobial activity [15]. In our study, MuellerHinton agar was used as the medium to determine the antimicrobial activity against bacteria.

Bacterial strains from stock cultures suspended in $5 \mathrm{~mL}$ of broth separately were incubated in an oven for 2 to 5 hours. At the end of this period, the bacterial suspension was adjusted to be $10^{8} \mathrm{cfu} / \mathrm{mL}$ and then $100 \mu \mathrm{L}$ was plated on each petri dish. A sterile swab was inoculated by drawing it in three different directions across the petri dish at frequent intervals. All petri dishes were then allowed to dry at room temperature for 5-15 minutes. At the end of the period, $50 \mu \mathrm{L}$ of $H$. reticulatus extract was transferred to wells of $5 \mathrm{~mm}$ in diameter on agar and the zone diameters were measured after 24 and 48 hours. Plates in which bacteria were inoculated were incubated at $35^{\circ} \mathrm{C}$ for 24 hours. At the end of this period, the diameters of the inhibition zones formed around the wells were measured. As a control, the solvent ethyl alcohol and water were inoculated on the same medium to check for inhibition. The antimicrobial activity experiments against all test microorganisms were done with three repetitions.

\subsection{X-ray Fluorescence (XRF) Spectrometric Method}

The powdered seeds were first filtrated by a sieve with diameter of $0.20 \mu \mathrm{m}$ and placed in the XRF wells (Bruker S8 Tiger), taking $3 \mathrm{~g}$ of the mixture. Elemental chemical analysis was then performed by XRF method and the $\%$ values of the elements in the plant were determined.

\subsection{Statistical Analysis}

Antimicrobial activity assays were performed with at least 3 replicates and each finding consisted of 2 repetitions. The data were analyzed by one-way ANOVA. Values of $\mathrm{p}<0.05$ were considered statistically significant. Statistical analyses were performed with SPSS 20 (IBM Corp., USA).

\section{RESULTS AND DISCUSSION}

\subsection{Antibacterial Test Results of $\boldsymbol{H}$. reticulatus Seed Extract}

The antibacterial test results of $H$. reticulatus seed extract are given in Table 1 . As shown in the table, the water-alcohol extract prepared from $H$. reticulatus seeds had low or no antibacterial effect against the tested bacteria.

Table 1. Zone diameters formed by $H$. reticulatus seed extract around tested bacteria.

\begin{tabular}{llc}
\multicolumn{1}{c}{ Test microorganisms } & Extract & $\begin{array}{c}\text { Inhibition Zones (mm) } \\
\text { Ethanol }\end{array}$ \\
\hline Escherichia coli & & - \\
Klebsiella pneumoniae & - & - \\
Pasteurella multocida & - & - \\
Pseudomonas aeruginosa & 10 & - \\
Staphylococcus aureus & - & - \\
Yersinia enterocolitica & - & - \\
Salmonella enteridis & - & - \\
\hline
\end{tabular}


When the antibacterial activity of $H$. reticulatus seed extract used in this study was examined, it was seen that the highest zone diameter was formed for $P$. multocida $(10 \mathrm{~mm})$ and it had no antibacterial effects on the other bacteria.

\subsection{X-ray Fluorescence (XRF) Spectrometric Method Results}

Table 2. The results of elemental analysis of H. reticulatus seed by XRF.

\begin{tabular}{llll}
\hline Formula & Concentration & Formula & Concentration \\
\hline $\mathbf{K}_{\mathbf{2}} \mathbf{O}$ & $1,98 \%$ & $\mathbf{K}$ & $1,65 \%$ \\
$\mathbf{P}_{\mathbf{2}} \mathbf{O}_{\mathbf{5}}$ & $1,22 \%$ & $\mathbf{P}$ & $0,53 \%$ \\
$\mathrm{SO}_{3}$ & $0,80 \%$ & $\mathbf{S}$ & $0,32 \%$ \\
$\mathbf{C a O}$ & $0,49 \%$ & $\mathbf{C a}$ & $0,35 \%$ \\
$\mathbf{F e}_{2} \mathbf{O}_{3}$ & $0,26 \%$ & $\mathbf{F e}$ & $0,18 \%$ \\
$\mathbf{C l}$ & $0,13 \%$ & $\mathbf{C l}$ & $0,13 \%$ \\
$\mathbf{M g O}$ & $0,11 \%$ & $\mathbf{M g}$ & $0,07 \%$ \\
$\mathbf{Z n O}$ & $0,10 \%$ & $\mathbf{Z n}$ & $0,08 \%$ \\
$\mathbf{M o O}_{3}$ & $0,06 \%$ & $\mathbf{M o}$ & $0,04 \%$ \\
$\mathrm{SiO}_{2}$ & $0,05 \%$ & $\mathbf{S i}$ & $0,02 \%$ \\
$\mathbf{C u O}$ & $0,02 \%$ & $\mathbf{C u}$ & $0,02 \%$ \\
$\mathbf{M n O}$ & $0,02 \%$ & $\mathbf{M n}$ & $0,01 \%$ \\
$\mathbf{A l} \mathbf{O}_{3}$ & $94 \mathrm{ppm}$ & $\mathbf{A l}$ & $50 \mathrm{ppm}$ \\
$\mathbf{N i O}$ & $67 \mathrm{ppm}$ & $\mathbf{N i}$ & $53 \mathrm{ppm}$ \\
\hline
\end{tabular}

In our study, elemental chemical analysis of powdered samples of $H$. reticulatus, which has medical potential, was performed by the XRF method. Thus, the \% values of the elements in this plant were determined. According to the results, the rate of $\mathrm{K}$, which was the most prevalent element, was $1.65 \%$, and $\mathrm{P}$ was $0.53 \%$. The $\%$ values of the other elements were similar. A trace amount of molybdenum (Mo: $0.06 \%$ ) was observed.

\section{CONCLUSIONS}

The results showed that the ethyl alcohol extract of $H$. reticulatus seeds used in this study had no antibacterial effects. However, Chalabian et al. reported that the alkaloids extracted from the flowers, stems, and roots of $H$. reticulatus and $H$. niger had a strong antimicrobial effect [16]. Bazzaz and Haririzadeh stated in their study that the methanol extract of the aboveground parts of $H$. reticulatus had antibacterial activity [17]. Therefore, it can be said in the present study that the antibacterial active substances in $H$. reticulatus seed have not been revealed due to the extraction method or solvent. Appropriate extraction methods can be investigated by determining the active ingredients responsible for the activity in the extract.

Hyoscyamus species contain high amounts of alkaloids such as atropine, hyoscyamine, and scopolamine. These compounds have potential acute or chronic toxicity $[18,19]$. The synthesis of alkaloids can be varied by external factors such as light, heat, altitude, soil structure, and nitrogen content in soil or herbicide applications. It is reported that there is a negative correlation between the $\mathrm{pH}$ of the soil and tropane alkaloids, and $\mathrm{pH}$ increases with elements such as $\mathrm{Ca}, \mathrm{N}, \mathrm{K}$, and $\mathrm{P}$ [20, 21, 22].

Yücel and Yilmaz stated that the levels of alkaloids in Hyoscyamus species can vary according to different areas in a region [23]. Potassium $(\mathrm{K})$, phosphorus $(\mathrm{P})$, copper $(\mathrm{Cu})$, zinc $(\mathrm{Zn})$, manganese $(\mathrm{Mn})$, iron (Fe), molybdenum (Mo), and boron (B) are essential elements for plant growth. Elements such as $\mathrm{Cu}, \mathrm{Zn}, \mathrm{Mn}$, and Mo are also heavy metals and their high concentrations are toxic to plants [24]. They are prone to accumulating in soil, clean water sources, and seawater.

According to the results in Table 2, the levels of $\mathrm{K}$ and $\mathrm{P}$, as the highest levels in the seed; the amount of molybdenum $(0.04 \%)$, which belongs to the heavy metals group; and the amounts of $\mathrm{Cu}, \mathrm{Zn}$, and $\mathrm{Si}$ 
are all not sufficient to cause toxic effects. In the attempts to fully characterize the plant, the most important purpose of our study is to investigate whether there are elements in the plant that cause toxic effects. In the results obtained by XRF spectroscopy, the oxide forms of the elements are also not sufficient to cause poisoning.

It has been stated that $H$. niger leaves and seeds are used by some young people in Anatolian villages due to their hallucinogenic effects, and when the seeds are used, particularly for that purpose, they can cause poisoning [25]. H. reticulatus is also used in Eastern Anatolia due to its hallucinogenic effects [26]. As a result, there are literature studies revealing that poisoning is caused by alkaloids.

In the literature studies, however, no comprehensive data have been found on the characterization and antimicrobial studies of $H$. reticulatus, and in this respect, our study will shed light on the work in this direction as a first undertaking in terms of a detailed characterization of the plant.

\section{REFERENCES}

[1] Baytop T, Türkiye'de Bitkilerle Tedavi, 2.baskı, Nobel Tıp Kitabevleri, 1999.

[2] Bahmanzadegan, A, Sefidkon, F, \& Sonboli A. Determination of hyoscyamine and scopolamine in four Hyoscyamus species from Iran. Iranian Journal of Pharmaceutical Research 2010; 65-70.

[3] Güler GÖ, Studies on antioxidant properties of the different solvent extracts and fatty acid composition of Hyoscyamus reticulatus L. J Food Biochem 2012; 36: 532-538.

[4] Williams MC, James LF. Effects of herbicides on the concentration of poisonous compounds in plants: A review. Am J Vet Res 1983; 44(12): 2420-2422.

[5] Karadaş S, Güler A, Şahin M, Behçet L. 32 haftalık gebede banotu zehirlenmesi. Van Tıp Derg 2012; 19 (1): 36-38.

[6] Kürkçüoğlu M. Henbane (Hyoscyamus niger) poisoning in the vicinity of Erzurum. Turk J Pediat 1970; 12(1): 48-56.

[7] Ulusoy H, Beşir A, Çıldır U, Koşucu M, Kutanis D. Pat pat otu (Hyoscyamus niger) alınımı sonrası gelişen antikolinerjik intoksikasyon. Klinik Toksikoloji Derneği 17. Kongresi Mardin, Özet Kitab1, (2012); 72-73.

[8] Singh, SK, \& Pandey VD, Evaluation of Hyoscyamus niger L. extracts for antibacterial activity. Plant Archives 2009; 9: 97-100.

[9] Dulger B, Goncu, BS, Gucin F. Antibacterial activity of the seeds of Hyoscyamus nige $\mathrm{r}$ L. (Henbane), Asian Journal of Chemistry 2010; 22: 6879-6883.

[10] Erkal H, Özyurt Y, Arıkan Z. Yaşlı hastada henbane (Hyoscyamus niger) sonrası antikolinerjik sendrom, Turk J Geriat 2006; 9: 188-191.

[11] Deveci HA, Nur G, Kırpık MA, Harmankaya A, Yıldız Y. Fenolik Bileşik İçeren Bitkisel Antioksidanlar, Kafkas Üniversitesi Fen Bil. Enst. Dergisi 2016; 9 (1): 26 - 32

[12] Meral R, Doğan İ. S, Kanberoğlu G.S. Fonksiyonel Gıda Bileşeni Olarak Antioksidanlar, Iğdır Üniversitesi Fen Bilimleri Enst. Dergisi 2012; 2(2): 45-50 
[13] Bali T. Süt, Süt Ürünlerinde ve Bu Ürünlerin Saklandığı Kaplarda XRF Tekniği Ile Ağır Metal Analizi, Yüksek Lisans Tezi, KSÜ Fen Bilimleri Enstitüsü,2011

[14] Allen, Malcolm S. Plant volatile analysis. Eds. Hans F. Linskens, and John F. Jackson, Springer, 1997:12 (43) 3371-3378.

[15] Submuth R, Eberspaecher J, Haag R and Sprınger W. Biochemisch Mikrobioogisches Prakticum, Thieme Verlag-Stuttgart 1987; 409.

[16] Chalabian F, Majd A, Mehrabian Saeid, Falahian F. A Study Of Growth Inhibitory Effect of Alkaloids of Two Species of Genus Hyoscyamus on Some Kinds Of Microbes of Skin 2002; 3371 3378.

[17] Bazzaz BS, \& Haririzadeh G. Screening of Iranian plants for antimicrobial activity, Pharmaceutical Biology 2003; 41(8): 573-583.

[18] Winston D. An introduction to herbal medicine, Nat Med 1994; 64: 346-353.

[19] Vike GM, Ufberg JW, Harrigan RA, Chan TC. Evaluation and treatment of acute urinary retention, J Emerg Med 2008; 35(2): 193-198.

[20] Chatterjee SK, Nandi RP, Baharati P, Yonjan MK. Improvement studies on some alkaloid yielding medicinal plants, Med Arom Spice Plants 1988; 180: 39-46.

[21] Poutaraud A, Girardin P. Influence of chemical characteristics of soil on mineral and alkaloid seed contents of Colchicum autumnale L. Environ Exp Bot 2005; 54: 101-108.

[22] Nejadhabibvash F, Rahmani F, Heidari R, Jamei R, Azimi F. Study of inheritance and environment on tropane alkaloids within Hyoscyamus species, AJCS 2012; 6 (10): 1428-1434.

[23] Yücel Mercan U, Yılmaz O. Van Yöresinde Yetişen İki Hyoscyamus (Banotu) Türünün Total Alkaloid Miktarları, YYU Veteriner Fakultesi Dergisi 2014; 25 (3): 77-80.

[24] Webber J. Trace metals in agriculture. Effect of heavy metal pollution on plants, Springer, Dordrecht 1981; 159-184.

[25] Yılmaz O. Bursa Yöresinde Yetişen Önemli Zehirli Bitkilerin Toksikolojik Özellikleri, Doktora Tezi, UÜ Sağ Bil Enst 1990.

[26] Kartal M, Kurucu S, Altun L, Ceyhan T, Sayar E, Cevheroğlu S, Yetkin Y. Quantitative analysis of 1-hyoscyamine in Hyoscyamus reticulatus L. By GC-MS, Turk J Chem 2003; 27: 565-569. 